\title{
Head and Neck Cancer a Single Institution Experience: King Abdulaziz University
}

\author{
Rolina K. Al-Wassia' ${ }^{1}$, MD, FRCPC, Nisreen A. Awad' ${ }^{1}$, MD, Rahaf A. Al Odaini, MD, \\ Shadi S. Al-Khayyat ${ }^{2}$, MD, FRCPC, Atlal M. Abusanad ${ }^{2}$, MD, FRCPC, \\ Hani Z. Al-Marzouki ${ }^{3}$, MD, FRCSC, Mohammed A. Attar' ${ }^{1}$, MD, DES(FR), \\ Talal A. Al Khatib ${ }^{3}$, MD, FRCSC, and Camelia T. Constantinescu, ${ }^{4}$, PhD \\ 'Department of Radiology, ${ }^{2}$ Department of Medicine, ${ }^{3}$ Department of Head and Neck Surgery \\ Faculty of Medicine, King Abdulaziz University and ${ }^{4}$ Department of Bio-Medical Physics, King Faisal \\ Specialist Hospital \& Research Center, Jeddah, Saudi Arabia
}

\section{Correspondence \\ Dr. Rolina K. Al-Wassia \\ P.O. Box 80215, Jeddah 21452, Saudi Arabia \\ e.M: ralwassia@kau.edu.sa \\ Submission: 15 Apr. 2015 \\ Accepted: 1 Jun 2015}

\section{Citation}

Al Wassia RK, Awad NA, Al Odaini RA, Al-Khayyat SS, Abusanad AM, Al-Marzouki HZ, Attar MA, Al Khatib TA, and Constantinescu CT. Head and neck cancer a single institution experience: King Abdulaziz University. JKAU Med Sci 2015; 22 (3): 9-17. DOl: 10.4197/Med. 22.3.2

\begin{abstract}
The purpose of this study is to assess the loco-regional control and overall survival in head and neck cancer patients, as well as evaluate the clinical benefit of intensity-modulated radiotherapy implemented in 2011 at our Hospital. Data of 117 patients between 2007 and 2014 was reviewed retrospectively. Cumulative survival and disease control rates were calculated by Kaplan-Meier product-limit actuarial method. Loco-regional control and survival rates for intensity modulated and three-dimensional conformal radiotherapy were compared by a logistic regression test. After a median follow-up of 12 months, $53(51 \%)$ patients who underwent radical radiotherapy were free of disease, 43 (42\%) with disease, and seven (7\%) unknown. During this time, 31 (26\%) patients died from the disease. Using actuarial estimates for the two-year follow-up, this study found that significant gains in survival were obtained by switching treatment modalities. The benchmarking gives reassurance that our results are comparable to the best clinical practices internationally.
\end{abstract}

\section{Keywords}

Head and neck cancer; Radiotherapy; Intensity modulated radiotherapy

\section{Introduction}

$H$ ead-and-neck squamous cell carcinoma (HNSCC) is the 6th leading incident cancer worldwide with more than 600,000 cases yearly and 53,600 cases diagnosed in the US in 2013 alone ${ }^{[1]}$. Males are affected significantly more than females with a ratio ranging from 2:1 to 4:1. HNSCC accounts for 3 percent of all malignancies and 12,000 are dying from the disease annually. Tobacco smoking and alcohol consumption are the predominant risk factors for HNSCC; human papilloma virus infection (for oropharynx), diet, physical activity, and nutrition also affect the risk of developing the disease ${ }^{[2-4]}$. Additionally, family history and genetic risk factors play a role in the development of head and neck cancers that is not yet well-defined ${ }^{[5]}$.

In Saudi Arabia, HNSCC is ranked $11^{\text {th }}$ of the highest cancer incidences reported. According to the Saudi Cancer Registry, the incidence of all head and 
neck cancer sub-sites is $7 \%$ of all cancers. Nasopharynx cancer ranks first among all head and neck cancers followed by larynx, tongue, oral cavity and or pharynx.

In the Kingdom more than half of the patients present with locoregionally advanced disease at diagnosis ${ }^{[6,7]}$; the treatment of which remains a clinical challenge that has to be refined and individualized for every case depending on several factors (age at diagnosis, primary disease stage, medical condition and organ function).

Surgery, radiotherapy and chemotherapy are the core treatment modalities for head and neck cancer in general. Radiotherapy and chemotherapy are fundamental parts of the management of patients in the adjuvant settings ${ }^{[8]}$ or as a radical treatment for nonresectable cancers and for organ function preservation, for example the larynx and oropharynx. The benefit of chemo-radiation on local control (LC) and overall survival (OS) is evidently documented in the literature ${ }^{[9]}$. Moreover, the use of new techniques like intensitymodulated radiotherapy (IMRT), tomotherapy, altered fractionation and concomitant chemotherapy improved the outcomes of treatment ${ }^{[10,11]}$. The utilization of IMRT has been adopted and utilized in our department since August 2011 for all head and neck cancer patients. With IMRT, the high dose areas are sculpted around the target volumes, with steep dose fall off immediately outside these regions, consequently allowing for highly conformal radiation dose delivery. The expedient use of IMRT significantly decreases toxicity and could possibly increase locoregional control (LRC) through important progress in the nonsurgical treatment of advanced HNSCC that has been evident in recent years ${ }^{[12]}$.

The purpose of this study is to present our experience in head and neck cancer at King Abdulaziz University Hospital and compare it to the published data.

\section{Method}

\section{Patients}

Between May 2007 and August 2015, 117 HNSSC patients were retrospectively reviewed at King Abdulaziz University Hospital. Pediatric patients (less than 14 years) were excluded from analysis.

All patients had confirmed pathological diagnosis in our center or reviewed for diagnosis confirmation. All patients had staging for the primary disease with computed tomography (CT) scan or magnetic resonance images (MRI) depending on the treating physician according to the latest American Joint Committee on Cancer staging version. Their demographic and clinical variables, such as age at the time of diagnosis, gender, cancer type, location, $T$ and $\mathrm{N}$ stage data were collected and analyzed (Table 1). The treatment intent and modality received (surgery, chemotherapy and radiation) are detailed in Table 1.

One hundred and three (88\%) patients were treated for curative intent with either concurrent chemoradiation protocol or adjuvant radiotherapy with chemotherapy if indicated. In this study only fourteen patients were treated for palliation and symptom control. Thirty-one (26\%) patients were treated with primary surgery followed by adjuvant radiotherapy with either 3D or with IMRT modality. Seventy-two (64\%) patients were treated with concurrent chemoradiation for curative intent.

\section{Radiation Therapy Treatment Protocol}

The mean prescribed dose for radical treatments was $64 \mathrm{~Gy}$ (range 50 - $70 \mathrm{~Gy}$ ), delivered with mean doses per fraction of $2 \mathrm{~Gy}$, (range $1.8-2.5 \mathrm{~Gy}$ ). For patients who underwent post-operative radiotherapy, the radiation dose was decided based on the pathological findings.

All patients who underwent complete resection with positive margins but no gross residual (R1) and or extra-capsular extension of nodal disease received 66 Gy in conventional fractionation, 2 Gy / Fraction daily 5 times per week. Patients with $\mathrm{R} 0$ resection at elevated risk for recurrence received $60 \mathrm{~Gy} / 30$ fractions. The radiotherapy treatment field included the surgical bed, the surgical scars, neck nodes with a greater than $10-15 \%$ risk of containing subclinical disease and anatomical sites at high-risk for loco-regional recurrence, following the Radiation Therapy Oncology Group (RTOG) Atlas for target volumes contouring. When radiotherapy was used as a primary curative treatment with or without chemotherapy, radiation dose was in the range of 66-70 Gy 33-35 fractions. Target volumes were contoured on axial CT scan slices. Gross primary and nodal tumors were contoured as gross tumor volume based on clinical findings and $\mathrm{CT}$ imaging or MRI done prior to neo-adjuvant chemotherapy. Clinical Target Volume (CTV) consisted of computer generated $1 \mathrm{~cm}$ expansions around each gross tumor volume respecting anatomical barriers to include areas at high risk of recurrence. The CTV also include non-dissected nodal groups with a greater than 
Table 1. Patient and tumor characteristics $(n=117)$.

\begin{tabular}{|c|c|c|c|}
\hline Characteristics & $\mathbf{N}(\%)$ & $\begin{array}{c}\text { IMRT } \\
(n=45)\end{array}$ & $\begin{array}{l}\text { 3D-CRT } \\
(n=72)\end{array}$ \\
\hline \multicolumn{4}{|l|}{ Age } \\
\hline Median & 48 & 49 & 50 \\
\hline Range & $16-93$ & $21-78$ & $16-93$ \\
\hline \multicolumn{4}{|l|}{ Gender } \\
\hline Females & 38 & $17(38.00 \%)$ & $21(29.00 \%)$ \\
\hline Males & 79 & $28(62.00 \%)$ & $51(71.00 \%)$ \\
\hline \multicolumn{4}{|l|}{ Primary Tumor Site } \\
\hline Nasopharynx & $38(33.00 \%)$ & $17(38.00 \%)$ & $21(29.00 \%)$ \\
\hline Larynx & $18(15.00 \%)$ & $5(11.00 \%)$ & $13(18.00 \%)$ \\
\hline Tongue & $18(15.00 \%)$ & $8(18.00 \%)$ & $10(14.00 \%)$ \\
\hline Maxilla & $7(6.00 \%)$ & $3(7.00 \%)$ & $4(6.00 \%)$ \\
\hline Hypopharynx & $7(6.00 \%)$ & $3(7.00 \%)$ & $4(6.00 \%)$ \\
\hline Buccal Mucosa & $5(4.00 \%)$ & $3(7.00 \%)$ & $2(3.00 \%)$ \\
\hline Others & $24(21.00 \%)$ & $6(12.00 \%)$ & $18(25.00 \%)$ \\
\hline \multicolumn{4}{|l|}{ Pathology } \\
\hline Squamous Cell Carcinoma & $74(63.00 \%)$ & $28(62.00 \%)$ & $46(64.00 \%)$ \\
\hline Undifferentiated Carcinoma & $29(25.00 \%)$ & $14(31.00 \%)$ & $15(21.00 \%)$ \\
\hline Others & $14(12.00 \%)$ & $3(7.00 \%)$ & $11(15.00 \%)$ \\
\hline \multicolumn{4}{|l|}{ TClassification } \\
\hline $\mathrm{T} 1$ & $19(17.00 \%)$ & $8(18.00 \%)$ & $11(15.00 \%)$ \\
\hline $\mathrm{T} 2$ & $27(23.00 \%)$ & $12(27.00 \%)$ & $15(21.00 \%)$ \\
\hline T3 & $25(21.00 \%)$ & $5(11.00 \%)$ & $20(28.00 \%)$ \\
\hline T4 & $43(37.00 \%)$ & $20(44.00 \%)$ & $23(32.00 \%)$ \\
\hline $\mathrm{Tx}$ & $3(2.00 \%)$ & $0(0.00 \%)$ & $3(4.00 \%)$ \\
\hline \multicolumn{4}{|l|}{ N Classification } \\
\hline No & $40(34.00 \%)$ & $10(22.00 \%)$ & $30(42.00 \%)$ \\
\hline N1 & $23(20.00 \%)$ & $10(22.00 \%)$ & $13(18.00 \%)$ \\
\hline N2 & $42(36.00 \%)$ & $21(47.00 \%)$ & $21(29.00 \%)$ \\
\hline $\mathrm{N} 3$ & $12(10.00 \%)$ & $4(9.00 \%)$ & $8(11.00 \%)$ \\
\hline \multicolumn{4}{|l|}{ Concomitant Chemotherapy } \\
\hline Yes & $25(22.00 \%)$ & $18(40.00 \%)$ & $7(9.00 \%)$ \\
\hline No & $88(75.00 \%)$ & $27(60.00 \%)$ & $61(85.00 \%)$ \\
\hline Unknown & $4(3.00 \%)$ & $0(0.00 \%)$ & $4(6.00 \%)$ \\
\hline \multicolumn{4}{|l|}{ Complete Surgical Resection } \\
\hline Yes & $31(26.00 \%)$ & $14(31.00 \%)$ & $17(24.00 \%)$ \\
\hline No & $86(74.00 \%)$ & $31(69.00 \%)$ & $55(76.00 \%)$ \\
\hline \multicolumn{4}{|l|}{ Radiotherapy Treatment Intent } \\
\hline Radical & $103(88.00 \%)$ & $44(98.00 \%)$ & $59(82.00 \%)$ \\
\hline Palliative & $14(12.00 \%)$ & $1(2.00 \%)$ & $13(18.00 \%)$ \\
\hline
\end{tabular}

$10-15 \%$ risk of containing subclinical disease. Planning target volume was constructed from an automated $0.3-0.5 \mathrm{~cm} 3 \mathrm{D}$ expansion of the CTV, to account for setup error and daily uncertainty. Dose limits for the critical tissue structures and plan evaluation were as defined by the RTOG-vs0225.

\section{Chemotherapy}

Twenty-five out of 117 patients received concomitant chemotherapy with radiation (Table 1). Eighteen patients in the IMRT received chemotherapy, however only eight patients received the 3D radiation modality (Table 1; shows 7 not 8). 
Chemotherapy was administrated concurrently with radiation or as neo-adjuvant and adjuvant, before and after chemotherapy, respectively. In Nasopharyngeal cancer, adjuvant chemotherapy is considered the standard of care following the treatment with concurrent chemo-radiotherapy but the administration of adjuvant chemotherapy in our center was limited due to patients' poor compliance. Alternatively, we used induction chemotherapy with TPF (docetaxel, cisplatinum and 5-FU) or cisplatinum and docetaxel as they present with large disease and compression symptoms that needed urgent and fast relief. Patients with locally advanced disease were offered TPF only if the performance status was good.

Cisplatinum was administrated concurrently as radio-sensitizer at $100 \mathrm{mg} / \mathrm{m}^{2}$ every 3 weeks or 30 $\mathrm{mg} / \mathrm{m}^{2}$ weekly. TPF is the protocol that was used for patients with nasopharyngeal cancer.

\section{Statistical Analysis}

Cumulative survival and disease control rates were calculated by Kaplan-Meier product-limit actuarial method. The closeout date for analysis was February 2015.

Locoregional control (LRC) and OS rates for IMRT and three-dimensional conformal RT (3D-CRT) were compared by a logistic regression test and a $\mathrm{p}$ value of $<0.05$ was considered significant.

\section{Results}

The median age was 48 , age range of $16-93$, with 38 females and 79 males. $63 \%$ of the patients had squamous cell cancer, $25 \%$ undifferentiated, and $12 \%$ other pathology.

One-hundred-three (88\%) patients received radical treatment while $14(12 \%)$ patients were treated with palliative radiotherapy.

Mean prescribed dose for radical treatments was $64 \mathrm{~Gy}$ (range 50 - $70 \mathrm{~Gy}$ ), delivered with mean dose per fraction of $2 \mathrm{~Gy}$ (range $1.8-2.5 \mathrm{~Gy}$ ).

After a median follow-up of 12 months (range: 1-84 months), 53 (51\%) patients who underwent radical RT were free of disease, 43 (42\%) with disease, and seven (7\%) unknown (Figs. 1, 2).

During this time, 30 (25\%) patients died from the disease, 22 (19\%) of them had received radical RT.
After a two-year follow-up, the actuarial estimate rates were: $70 \%$ for local control, $91 \%$ for nodal control and $90 \%$ for distant control (Fig. 3). No significant difference was found in LRC between IMRT and 3D-CRT (Fig. 4). On differential analysis, after a two- year follow-up, the actuarial estimate rates were: $70 \%$ for local control $(p=0.54), 91 \%(p=0.80)$ for nodal control and $63 \%$ vs. $70 \%(p=0.27)$ for LRC in IMRT, respectively 3D-CRT (Table 2, Fig. 5).

Significant differences between IMRT and 3D-CRT were found in survival (Fig. 5). The actuarial estimate rates at two years were: $87 \%$ vs. $73 \%(p=0.0453)$ for OS and $64 \%$ vs. $52 \%(p=0.0421)$ for disease-free survival (DFS) in IMRT, respectively 3D-CRT (Fig. 6).

Due to the small number of patients, further subgroup analysis with respect to diagnosis, age or gender was not performed.

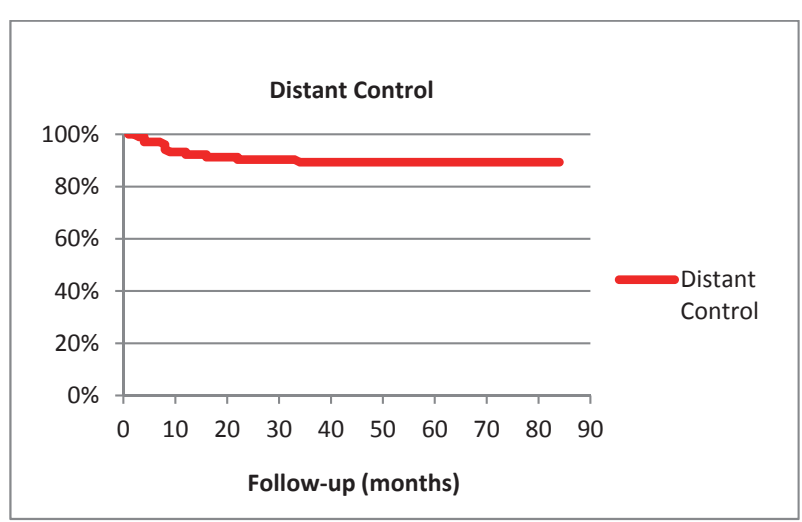

Figure 1. Distant control for all patients who received radiotherapy.

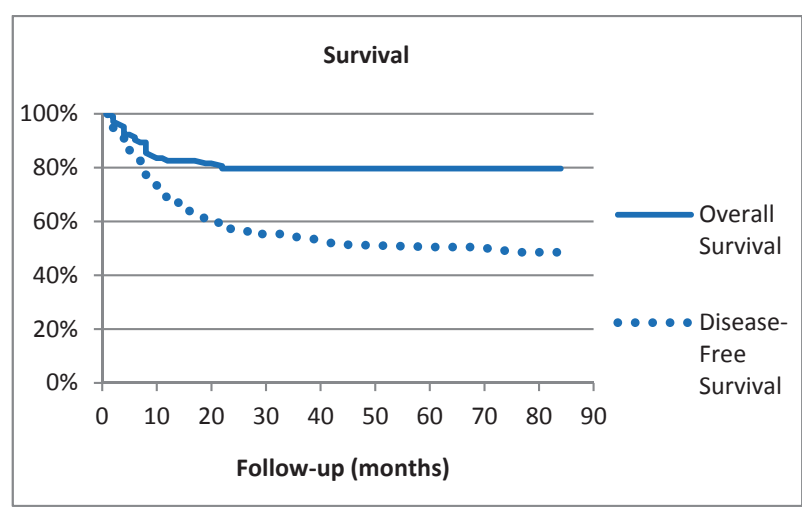

Figure 2. Survival for all patients receiving radical $R T(n=103)$. 


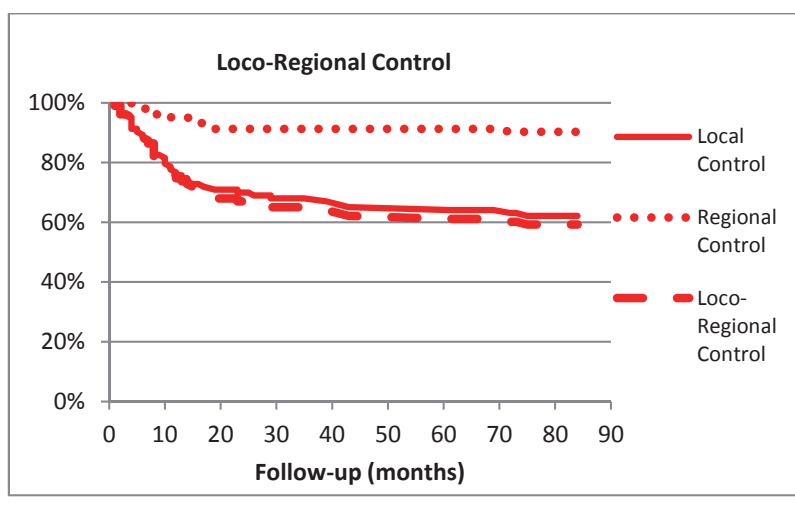

Figure 3. Disease control for all patients receiving radical RT $(n=103)$.

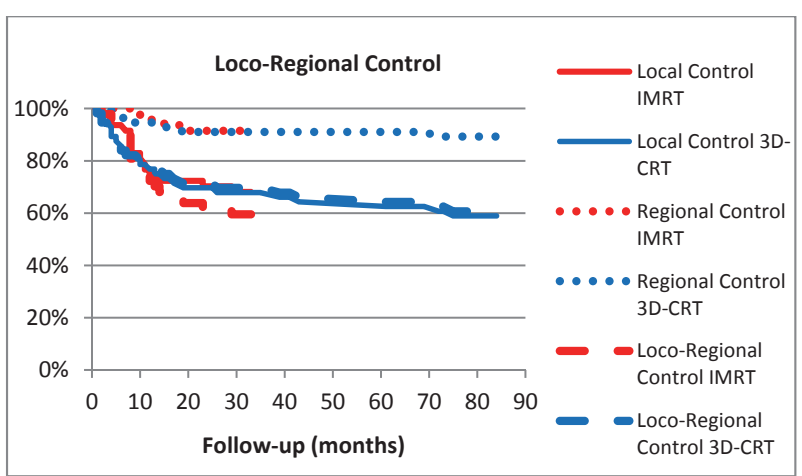

Figure 4. Comparison of disease control between intensity modulated radiotherapy (IMRT) and three-dimensional conformal radiotherapy (3D-CRT).

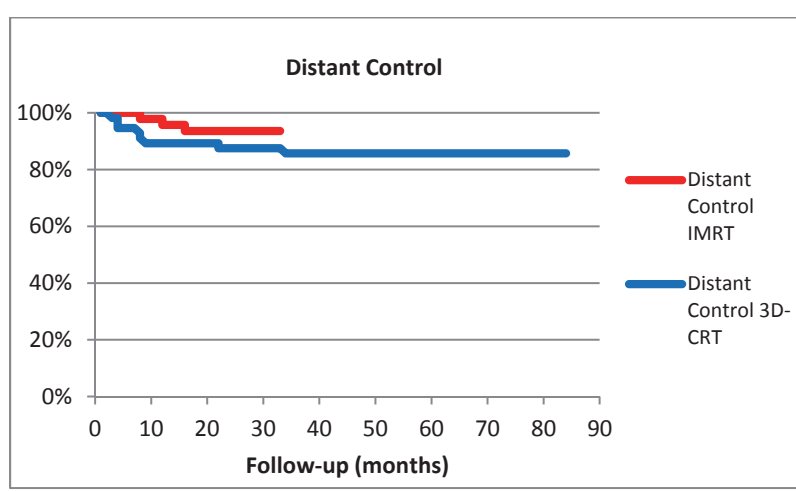

Figure 5. Comparison of distant control between intensity modulated radiotherapy (IMRT) and three dimensional radiotherapy (3D-RT)

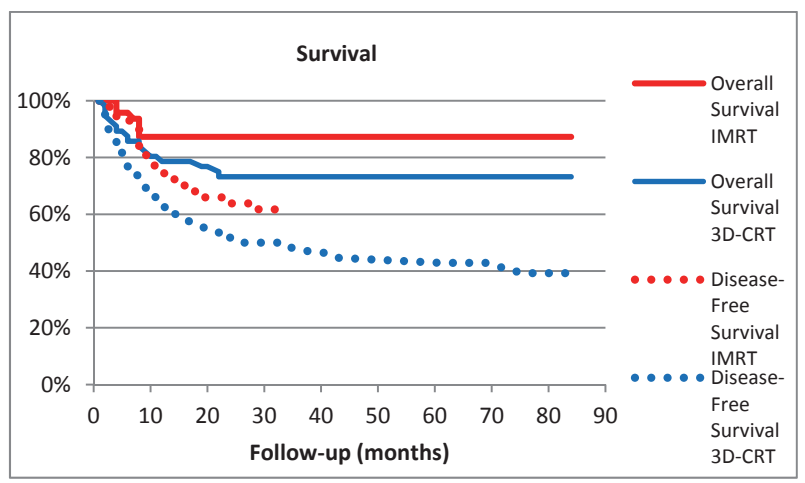

Figure 6. Comparison of survivals between intensity modulated radiotherapy (IMRT) and three-dimensional conformal RT (3D-CRT).

Table 2. Comparison of locoregional control and survival between IMRT and 3D-CRT for radical treatment $(n=103)$.

\begin{tabular}{|c|c|c|c|}
\hline Characteristic & n (\%) & $\begin{array}{c}\text { IMRT } \\
(n=44)\end{array}$ & $\begin{array}{c}\text { 3D-CRT } \\
(n=59)\end{array}$ \\
\hline \multicolumn{4}{|l|}{ Follow-up } \\
\hline Median & 12 & 14 & 13 \\
\hline Range & $1-84$ & $1-41$ & $1-84$ \\
\hline \multicolumn{4}{|l|}{ Clinical Outcome } \\
\hline Free of Disease & $53(51.00 \%)$ & $26(59.00 \%)$ & $27(46.00 \%)$ \\
\hline Loco-Regional Relapse & $33(32.00 \%)$ & $15(34.00 \%)$ & $20(34.00 \%)$ \\
\hline Mets & $10(10.00 \%)$ & $3(7.00 \%)$ & $7(12.00 \%)$ \\
\hline Died & $23(22.00 \%)$ & $8(18.00 \%)$ & $15(25.00 \%)$ \\
\hline Unknown & $7(7.00 \%)$ & $2(4.00 \%)$ & $5(8.00 \%)$ \\
\hline
\end{tabular}

Abbreviations: IMRT = intensity modulated radiotherapy; $3 D-C R T=$ three-dimensional conformal radiotherapy 


\section{Discussion}

In the current review, we present our experience at King Abdulaziz University Hospital, switching from threedimensional radiotherapy (3D-RT) to IMRT. This study also reports the results of our practice for all head and neck sub-sites and compares it to the published data.

It was not unexpected to find out that the cases that received the radiotherapy as IMRT technique resulted in similar loco-regional control rates, but significantly higher survival rates, when compared to 3D-CRT. We think this observation goes with the improvement in the chemotherapy availability at the time radiation had followed the state of the art. Only $7 \%$ of the patients treated with 3D-RT, received chemotherapy in comparison to $40 \%$ in the IMRT group. In addition the percentage of the advanced cancer were slightly higher in the 3D-RT group, (60\%), and 55\% in the IMRT group. Also we think is it difficult to compare the results of the two modalities as they have different patients, treatments, periods, and follow-ups.

The outcomes of the group of patients treated with IMRT are comparable to the published reports from different international centers. In this review, the two-year rates for OS, DFS, local control, nodal control, and LRC are $87 \%, 64 \%, 70 \%, 91 \%$ and $63 \%$, respectively. Studer et al. ${ }^{[15]}$. reported their results for 280 head and neck patients treated with IMRT. Chemotherapy was given in $85 \%$, and $71 \%$ of patients were treated with definitive and post-op radiotherapy, respectively. The two-year rates for OS, DFS, local control, and nodal control were $82 \%, 73 \%, 80 \%$, and $87 \%$, respectively ${ }^{[15]}$. Schoenfeld et al. ${ }^{[16]}$ published the outcome of 100 head and neck patients treated with IMRT. All patients received definitive radiotherapy and $54 \%$ were treated concomitantly with chemotherapy. The three-year rates for OS, DFS, local control, and LRC were $71 \%, 77 \%, 87 \%$, and $72 \%$, respectively ${ }^{[16]}$. In 2012 , Vlacich et al. ${ }^{[17]}$ published the outcome of 150 patients of head and neck cancer treated with IMRT. All patients had advanced disease (stage III and IV) and all of them received concurrent chemotherapy, and most of the patients $(67 \%)$ received induction chemotherapy. The two-year rates of OS, DFS, local recurrence-free survival, and loco-regional recurrence-free survival were $82 \%$, $83 \%, 88 \%$, and $89 \%$, respectively ${ }^{[17]}$. Similar results are published in other reports ${ }^{[18,19]}$. Table 3 summarizes the outcomes of this review in comparison with other published data. We noticed lower rates of DFS and LRC in our review for the patients treated with IMRT, this could be due to the smaller percentage of patients (40\%) who received chemotherapy, though more than half of the patients have advanced disease (T3 or N2 and higher). Also, a smaller number of patients ( 45 patients only) may affect the real results (Table 3 ).

Looking at the end outcomes, it is still reasonable and satisfying for the treating team to consider King Abdulaziz University as a leading center in the field of Head and Neck Oncology.

The last few years have seen tremendous improvement in the supportive services at our institute including nutrition, psychiatry, palliative care and social work referrals. Our prospects for the future include optimizing patients' care, improving treatment outcomes and increasing community awareness regarding the importance of early presentations and risk reduction measures.

\section{Conclusion}

Post-operative IMRT resulted in similar loco-regional control rates, but significantly higher survival rates, when compared to 3D-CRT. The results reflect the past unavailability of chemotherapy at our institute. The benchmarking gives reassurance that practice in our center is comparable to the best clinical practices internationally.

Table 3. Outcomes of different published data.

\begin{tabular}{|c|c|c|c|c|c|c|c|c|}
\hline Report & No. & FU-rate & Chemotherapy \% & OS\% $\%$ & DFS $\%$ & LC\% & NC\% & LRC $\%$ \\
\hline Current Review & 45 & $2 Y$ & $40 \%$ & $87 \%$ & $64 \%$ & $70 \%$ & $91 \%$ & $63 \%$ \\
\hline Studer et al. ${ }^{[15]}$ & 280 & $2 Y$ & $\begin{array}{l}85 \text { definitive } \\
71 \text { pos-op }\end{array}$ & $82 \%$ & $73 \%$ & $80 \%$ & $87 \%$ & N \\
\hline Schoenfeld et al. ${ }^{[16]}$ & 100 & $3 Y$ & $54 \%$ & $71 \%$ & $77 \%$ & $87 \%$ & & $72 \%$ \\
\hline Vlacich et al. ${ }^{[17]}$ & 150 & $2 Y$ & $100 \%$ & $82 \%$ & $83 \%$ & $88 \%$ & - & $89 \%$ \\
\hline Yao et al. ${ }^{[18]}$ & 150 & $2 Y$ & $69 \%$ & $85 \%$ & - & $94 \%$ & - & $92 \%$ \\
\hline
\end{tabular}


Head and Neck Cancer a Single Institution Experience: King Abdulaziz University

R.K. Al-Wassia et al.

\section{Acknowledgment}

The authors would like to thank all the doctors, nurses, physicist and therapists that participated in the treatment of the patients in our study. Special thanks go to Dr. Iqbal Maniyar for his dedication and great help.

\section{Conflict of Interest}

The authors have no conflict of interest.

\section{Disclosure}

None of the authors received any type of commercial support either in forms of compensation or financial for this study. They have no financial interest in any of the products or devices, or drugs mentioned in this article.

\section{Ethical Approval}

Obtained.

\section{References}

[1] Siegel R, Naishadham D, Jemal A. Cancer statistics, 2013. CA Cancer J Clin 2013; 63(1): 11-30.

[2] Hashibe M, Brennan P, Benhamou S, Castellsague X, Chen C, Curado MP, Dal Maso L, Daudt AW, Fabianova E, Fernandez L,Wünsch-Filho V, Franceschi $S$, Hayes RB, Herrero R, Koifman S, La Vecchia C, Lazarus P, Levi F, Mates D, Matos E, Menezes A,Muscat J, Eluf-Neto J, Olshan AF, Rudnai P, Schwartz SM, Smith E, Sturgis EM, Szeszenia-Dabrowska N, Talamini R, Wei Q, Winn DM, Zaridze D, Zatonski W, Zhang ZF, Berthiller J, Boffetta P. Alcohol drinking in never users of tobacco, cigarette smoking in never drinkers, and the risk of head and neck cancer: pooled analysis in the International Head and Neck Cancer Epidemiology Consortium. J Natl Cancer Inst 2007; 99(10): 777-789.

[3] Nicolotti N, Chuang SC, Cadoni G, Arzani D, Petrelli L, Bosetti C, Brenner H, Hosono S, La Vecchia C, Talamini R, Matsuo K, Müller H, Muscat J, Paludetti G, Ricciardi G, Boffetta P, Hashibe M, Boccia S. Recreational physical activity and risk of head and neck cancer: a pooled analysis within the international head and neck cancer epidemiology (INHANCE) Consortium. Eur J Epidemiol 2011; 26(8): 619628.

[4] Marks MA, Chaturvedi AK, Kelsey K, Straif K, Berthiller J, Schwartz SM, Smith E, Wyss A, Brennan P, Olshan AF, Wei Q,Sturgis EM, Zhang ZF, Morgenstern H, Muscat J, Lazarus P, McClean M, Chen C, Vaughan TL, Wunsch-Filho V, Curado MP,Koifman S, Matos E, Menezes A, Daudt AW, Fernandez L, Posner M, Boffetta P, Lee YC, Hashibe M, D'Souza G. Association of marijuana smoking with oropharyngeal and oral tongue cancers: pooled analysis from the INHANCE consortium. Cancer Epidemiol Biomarkers Prev 2014; 23(1): 160-171.

[5] Leoncini E, Vukovic V, Cadoni G, Pastorino R, Arzani D, Bosetti C, Canova C, Garavello W, La Vecchia C, Maule M, Petrelli L, Pira E, Polesel J, Richiardi L, Serraino D, Simonato L, Ricciardi W, Boccia S. Clinical features and prognostic factors in patients with head and neck cancer: Results from a multicentric study. Cancer Epidemiol 2015; 39(3): $367-$ 374.

[6] Al-Herabi AZ. Head and neck oncology experience in Makkah, Saudi Arabia. Saudi Med J 2009; 30(10): 1316 1322.

[7] Laramore GE, Clubb B, Quick C, Amer MH, Ali M, Greer W, Mahboubi E, el-Senoussi M, Schultz H, el-Akkad SM. Nasopharyngeal carcinoma in Saudi Arabia: a retrospective study of 166 cases treated with curative intent. Int J Radiat Oncol Biol Phys 1988; 15(5): 1119-1127.

[8] Cooper JS, Zhang Q, Pajak TF, Forastiere AA, Jacobs J, Saxman SB, Kish JA, Kim HE, Cmelak AJ, Rotman M, Lustig R, Ensley JF, Thorstad W, Schultz CJ, Yom SS, Ang KK. Longterm follow-up of the RTOG 9501/intergroup phase III trial: postoperative concurrent radiation therapy and chemotherapy in high-risk squamous cell carcinoma of the head and neck. Int J Radiat Oncol Biol Phys 2012; 84(5): 1198-1205.

[9] Adelstein DJ1, Saxton JP, Lavertu P, Rybicki LA, Esclamado RM, Wood BG, Strome M, Carroll MA. Maximizing local control and organ preservation in stage IV squamous cell head and neck cancer With hyperfractionated radiation and concurrent chemotherapy. J Clin Oncol 2002; 20(5): 1405-1410.

[10] Rütten H, Pop LA, Janssens GO, Takes RP, Knuijt S, Rooijakkers $A F$, van den Berg M, Merkx MA, van Herpen CM, Kaanders JH. Long-term outcome and morbidity after treatment with accelerated radiotherapy and weekly cisplatin for locally advanced head-and-neck cancer: results of a multidisciplinary late morbidity clinic. Int J Radiat Oncol Biol Phys 2011; 81(4): 923-929.

[11] Ghadjar P1, Simcock M, Zimmermann F, Betz M, Bodis S, Bernier J, Studer G, Aebersold DM; Swiss Group for Clinical Cancer Research (SAKK). Predictors of severe late radiotherapy-related toxicity after hyperfractionated radiotherapy with or without concomitant cisplatin in locally advanced head and neck cancer. Secondary retrospective analysis of a randomized phase III trial (SAKK 10/94). Radiother Oncol 2012; 104(2): 213-218.

[12] Marta GN, Silva V, de Andrade Carvalho H, de Arruda FF, Hanna SA, Gadia R, da Silva JL, Correa SF, Vita Abreu CE, Riera R. Intensity-modulated radiation therapy for head and neck cancer:systematic review and meta-analysis. Radiother Oncol 2014; 110(1): 9-15.

[13] Xu JH, Guo WJ, Bian XH, Wu JF, Jiang XS, Guo YS, He $X$. A comparative study of locoregionally advanced nasopharyngeal carcinoma treated with intensity 
modulated irradiation and platinum-based chemotherapy. Cancer Radiother 2013; 17(4): 297-303.

[14] Colaco RJ, Betts G, Donne A, Swindell R, Yap BK, Sykes AJ, Slevin NJ, Homer JJ, Lee LW. Nasopharyngeal carcinoma: a retrospective review of demographics, treatment and patient outcome in a single centre. Clin Oncol (R Coll Radiol) 2013; 25(3): 171-177.

[15] Studer G, Luetolf UM, Glanzmann C. Locoregional failure analysis in head-and-neck cancer patients treated with IMRT. Strahlenther Onkol 2007; 183(8): 417-423.

[16] Schoenfeld GO, Amdur RJ, Morris CG, Li JG, Hinerman RW, Mendenhall WM. Patterns of failure and toxicity after intensity-modulated radiotherapy for head and neck cancer. Int J Radiat Oncol Biol Phys 2008; 71(2): 377-385

[17] Vlacich G, Diaz R, Thorpe SW, Murphy BA, Kirby W, Sinard RJ, Shakhtour B, Shyr Y, Murphy P, Netterville JL, Yarbrough WG, Cmelak AJ. Intensity-modulated radiation therapy with concurrent carboplatin and paclitaxel for locally advanced head and neck cancer: toxicities and efficacy. Oncologist 2012; 17(5): 673-681.

[18] Yao M, Dornfeld KJ, Buatti JM, Skwarchuk M, Tan H, Nguyen T, Wacha J, Bayouth JE, Funk GF, Smith RB, Graham SM, Chang K, Hoffman HT. Intensity-modulated radiation treatment for head-and-neck squamous cell carcinomathe University of lowa experience. Int J Radiat Oncol Biol Phys 2005; 63(2): 410-421

[19] Sher DJ, Balboni TA, Haddad RI, Norris CM Jr, Posner MR, Wirth LJ, Goguen LA, Annino D, Tishler RB. Efficacy and toxicity of chemoradiotherapy using intensity-modulated radiotherapy for unknown primary of head and neck. Int J Radiat Oncol Biol Phys 2011; 80(5): 1405-1411. 


\section{تجربة مستشفى جامعة الملك عبدالعزيز مع أورام الرأس والرقبة}

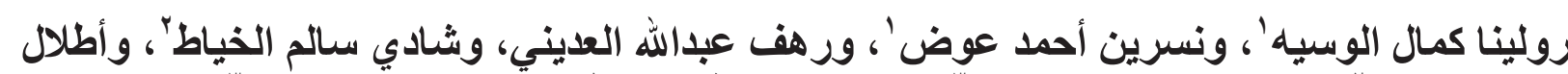

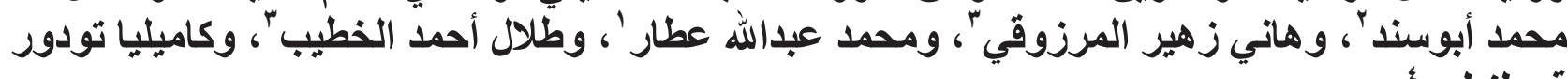

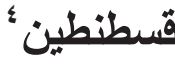

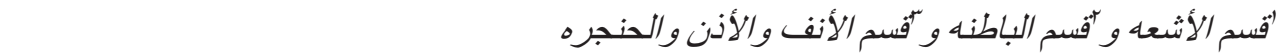

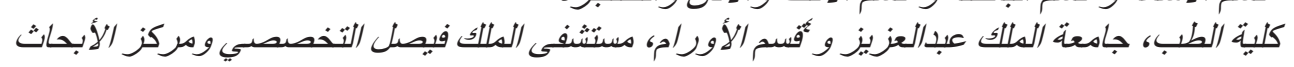

$$
\begin{aligned}
& \text { جلة ـ المملكة العربية السعودية السية }
\end{aligned}
$$

المستخطص. غرض دراستنا هو تقييم ضبط التحكم الموضعي في الورم، و البقاء على قيد الحياة في مرضى سرطان الر أس

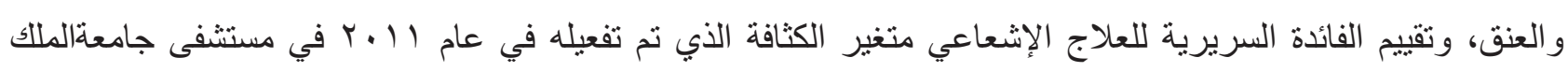

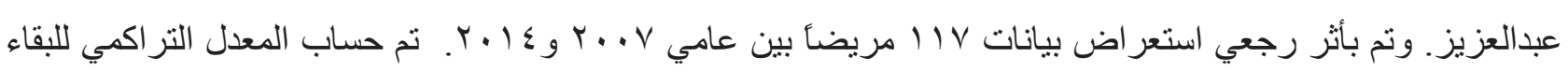

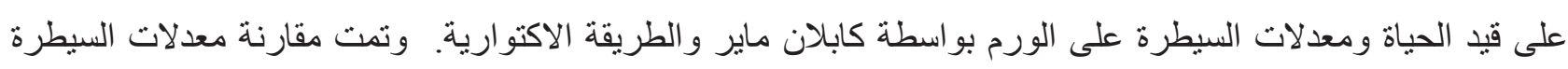

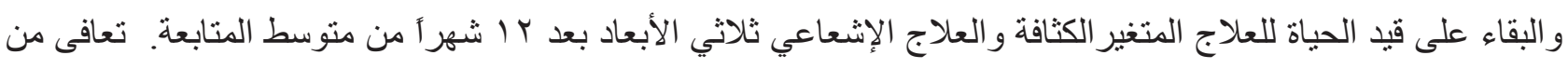

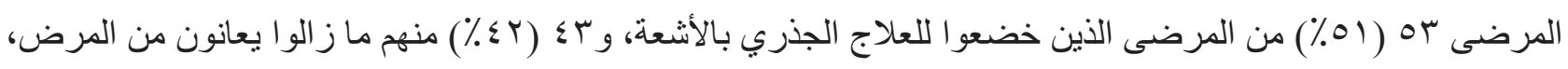

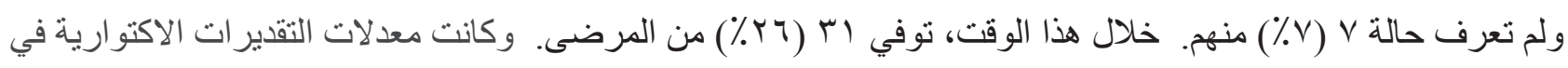

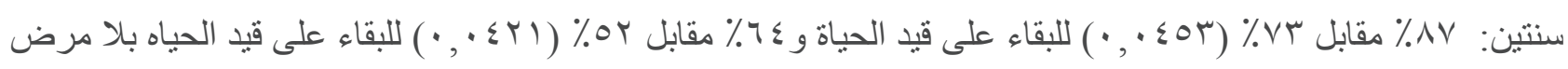

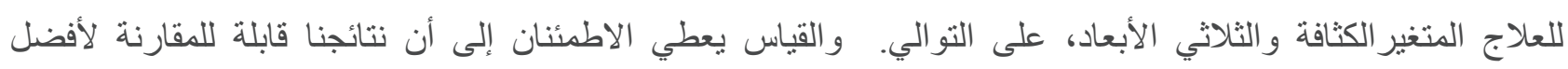
الممارسات السريرية على الصعيد الدولي. 